УДК 656.029.4

\title{
УДОСКОНАЛЕННЯ ТЕХНОЛОГІЇ ОПЕРАТИВНОГО ПЛАНУВАННЯ ВАНТАЖНОӤ РОБОТИ ПРИ ВЗАСМОДІЇ ВЛАСНИКІВ РУХОМОГО СКЛАДУ ІЗ ЗАЛІЗНИЦЕЮ
}

Доктори техн. наук О.В. Лаврухін, В.С. Блиндюк, асист. Г.С. Богомазова, асп. А.М. Киман, магістри М.О. Тофан, Р.Б. Розумович

\section{УСОВЕРШЕНСТВОВАНИЕ ТЕХНОЛОГИИ ОПЕРАТИВНОГО ПЛАНИРОВАНИЯ ГРУЗОВОЙ РАБОТЫ ПРИ ВЗАИМОДЕЙСТВИИ СОБСТВЕННИКОВ ПОДВИЖНОГО СОСТАВА С ЖЕЛЕЗНОЙ ДОРОГОЙ}

Доктора техн. наук А.В. Лаврухин, В.С. Блиндюк, ассист. А.Е. Богомазова, асп. А.Н. Киман, магистры М.О. Тофан, Р.Б. Розумович

\section{IMPROVEMENT THE TECHNOLOGY OF OPERATIONAL PLANNING OF CARGO WORK IN THE INTERACTION OWNERS OF ROLLING STOCK WITH RAILWAYS}

Doctors of techn. sciences O. Lavruhin, V. Blindyuk, assistant G. Bogomazova, graduate student A. Kiman, masters M. Tofan, R. Rozumovych

Розглядається організація роботи залізничного транспорту з промисловими підприємствами. Виявлено недоліки в технології оперативного планування вантажної роботи на залізнииях України. Запропонована оптимізаційна модель розрахунку оперативного плану вантажної роботи залізничної станиії із системою обмежень. Пропонується створення єдиної системи управління парком вантажних вагонів для взаємозаміни вагонів різних форм власності у випадку нестачі того чи іншого рухомого складу.

Ключові слова: власні вагони операторів, інвентарний парк, резервний парк вагонів, оперативне планування.

Рассматривается организачия работы железнодорожного транспорта с промышленными предприятиями. Выявлены недостатки в технологии оперативного планирования грузовой работой на железных дорогах Украины. Предложена оптимизаџионная модель расчета оперативного плана грузовой работы железнодорожной станиии с системой ограничений. Предлагается создание единой системы управления парком грузовых вагонов для взаимозамены вагонов различных форм собственности в случае недостачи того или иного подвижного состава.

Ключевые слова: собственные вагоны операторов, инвентарный парк, резервный парк вагонов, оперативное планирование.

We considered the organization of work of rail transport with industry. The deficiencies in operational planning in freight work on railroads of Ukraine are revealed. We are proposed the optimization model on calculation of the operational plan of the cargo work on railway station with system limitations. The paper proposes the creation of a unified system control of cargo wagons park for cars interchange the different forms of ownership in the event of a shortage of that or another rolling stock. Such reserve park of wagons allows the replacement of private cars on inventory and vice versa. Thus, owners of rolling stock reduces the risk of maintenance costs wagon unproductive downtime or delay in supply wagons for loading due to their shortage. Under this system, the railway compensates the lack of rolling stock using the own carrier wagons of operator companies. This will expand the cargo and customer database.

Keywords: operators of own wagons, inventory park, reserve park of wagons, operational planning.

Вступ. В сучасних умовах ринкових відносин між виробниками і споживачами матеріальних ресурсів ускладнюється організація роботи транспорту з промисловими підприємствами. В сфері транспорту задіяні великі людські і матеріальні ресурси, в тому числі рухомий склад, вантажнорозвантажувальні машини. Від ефективності 


\section{Експлуатація залізниць}

використання ресурсів істотно залежить собівартість продукції та рентабельність залізниці. Це можливо досягти за рахунок удосконалення існуючих технологій взаємодії залізничного транспорту із клієнтами.

Неузгодженість між роботою залізниці та замовниками послуг на перевезення продукції, у своїй більшості, обумовлюється недосконалою діючою системою оперативного планування та управління перевізним процесом. Оперативне планування вантажної роботи на залізницях України $є$ важливою складовою системи організації перевізного процесу i повинно забезпечувати виконання норм навантаження, вивантаження, передачі поїздів і вагонів на суміжні 3 Україною держави, між залізницями i дирекціями, здавання порожніх вагонів в регулювання, виконання технічних норм використання рухомого складу, нормативів графіка руху. Оперативне планування є важливим засобом в забезпеченні рівномірності в поїзній і вантажній роботі [1].

Постановка проблеми у загальному вигляді. На даний час актуальні такі методи планування розподілу обмеженого матеріального ресурсу, які спрямовані на удосконалення технології роботи основних залізничних підрозділів 3 безумовною орієнтацією їх діяльності на задоволення основних потреб клієнтів (своєчасне надання вагонів для перевезення, під навантаження та розвантаження, доставка вантажу точно у строк та його схоронність), а також додаткових послуг, до яких відноситься надання оперативної та достовірної інформації у реальному режимі часу щодо знаходження вагонів. Виникає необхідність оцінки ефективності використання рухомого складу 3 точки зору клієнтури та 3 позиції отримання максимального прибутку для Укрзалізниці.

Згідно 3 даними Укрзалізниці, спостерігаються коливання обсягів навантаження (рис. 1) та вивантаження (рис. 2) загалом по залізницях, що обумовлено i сезонним фактором також. Мінливість перевезення вантажів спричиняє труднощі із просуванням вагонопотоків при плануванні оперативної роботи полігонів залізниці. Ця нерівномірність негативно відбивається на раціональному використанні рухомого складу.

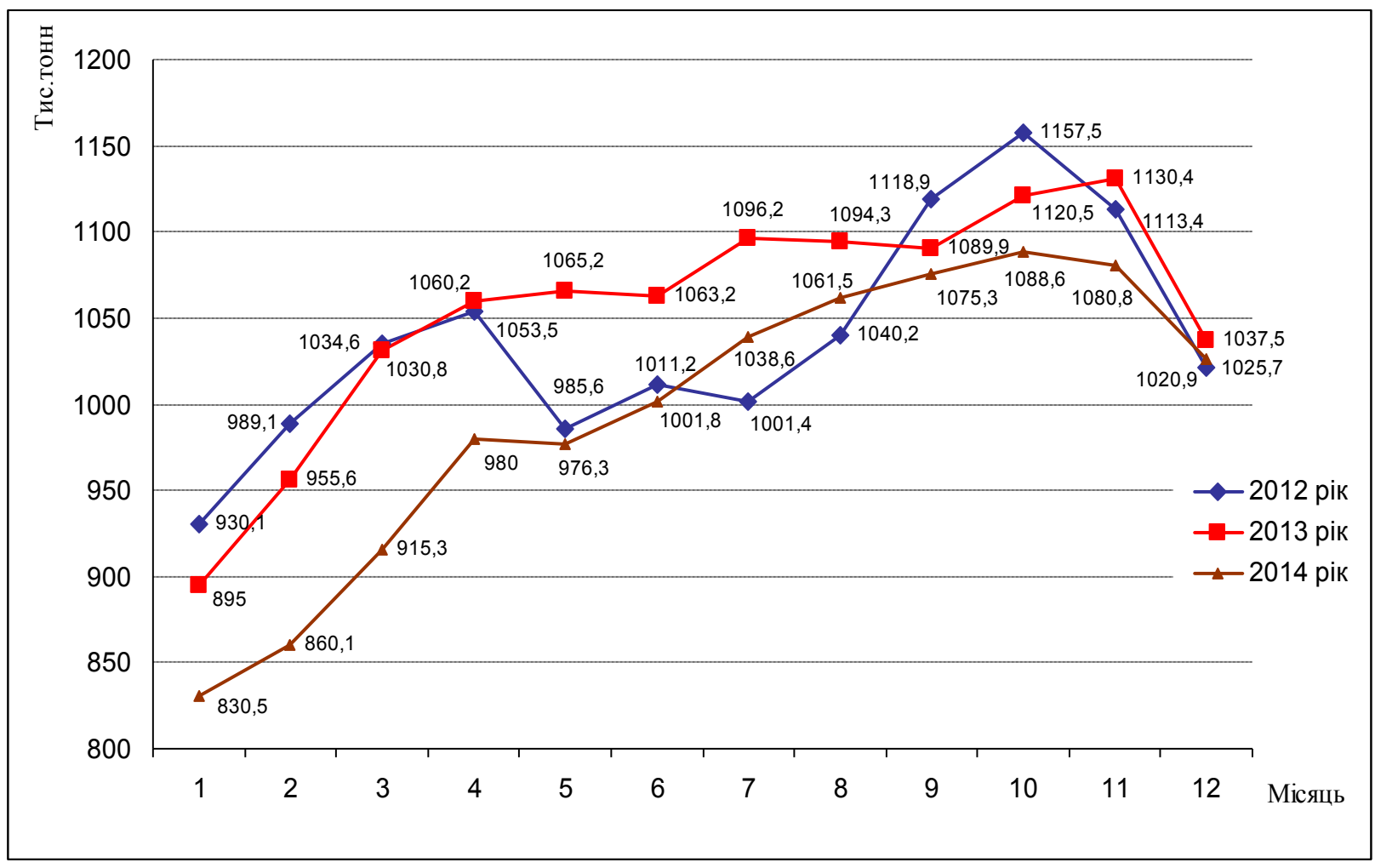

Рис. 1. Динаміка зміни середньодобового навантаження в тисячах тонн по Укрзалізниці за місяцями 


\section{Експлуатація залізниць}

Коливання обсягів перевезень відбувається при збільшені або зменшені обсягів роботи, що ускладнюе процес планування поїздо- і вагонопотоків. При щорічному скорочені робочого інвентарного парку вагонів (рис. 3), існування проблеми раціонального використання засобів транспорту посилюється.

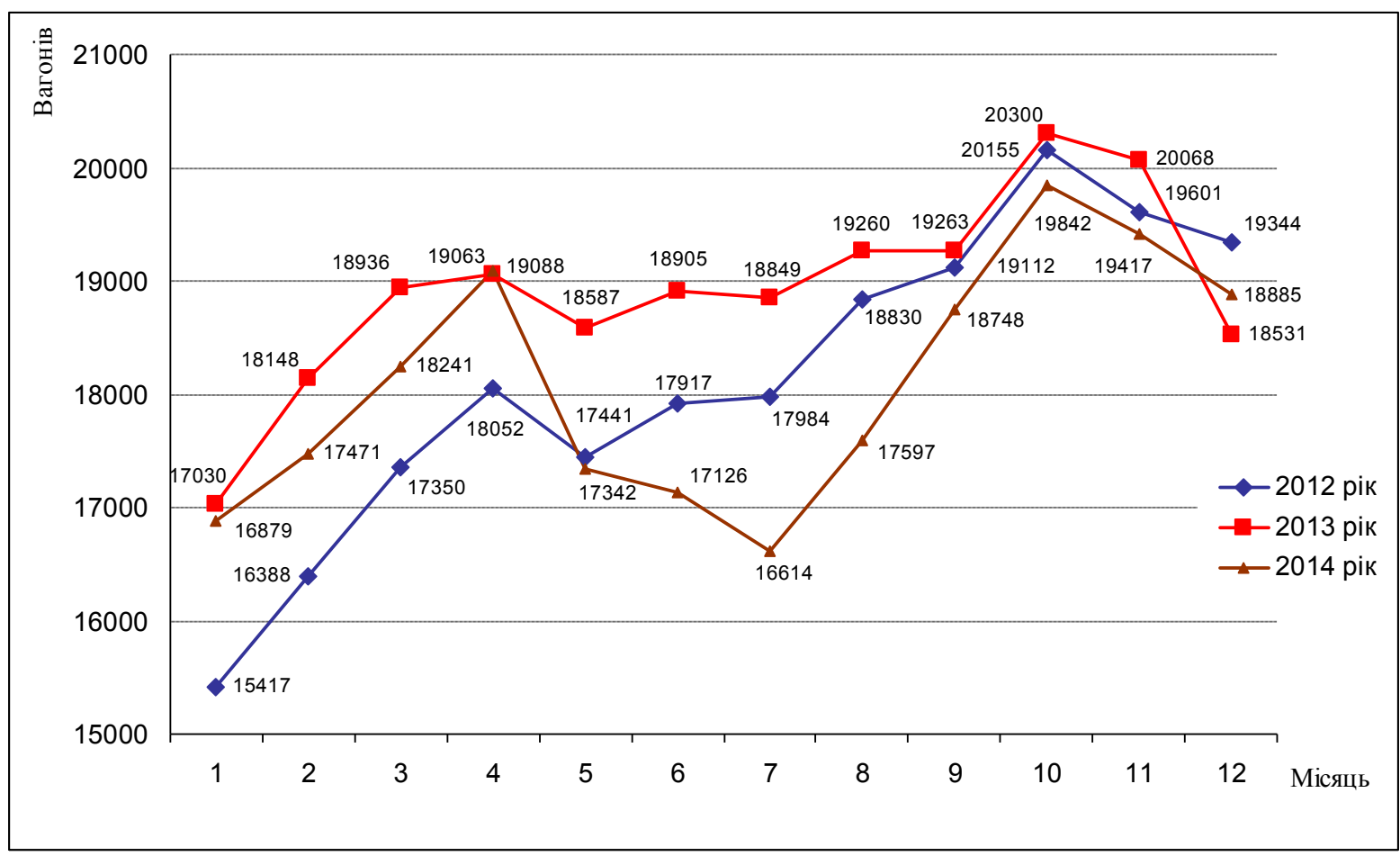

Рис. 2. Динаміка зміни середньодобового вивантаження у вагонах по Укрзалізниці за місяцями

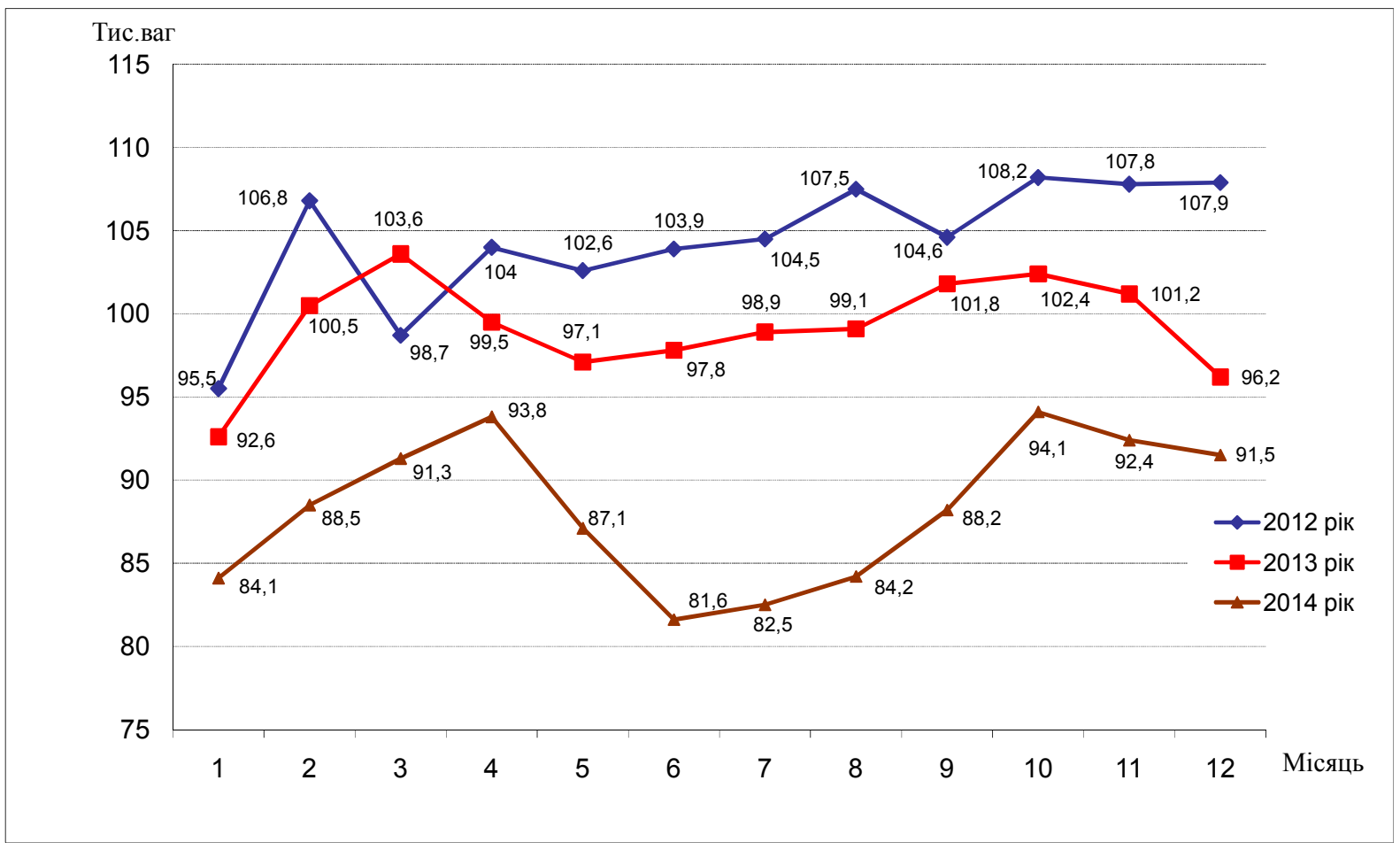

Рис. 3. Динаміка зміни середньодобового робочого парку вагонів по Укрзалізниці за місяцями 
Від ефективної організації вантажних вагонопотоків на залізничному транспорті значною мірою залежить ритм роботи всієї мережі. Однак, як показали дослідження, за наявності великої кількості власників рухомого складу вирішити цю задачу вельми непросто. До того ж, на формування попиту на вантажні вагони впливають випадкові події, а це призводить до змін термінів і обсягів перевезених вантажів, що вирішується в оперативному порядку.

Аналіз останніх досліджень і публікацій. Роботи [2-4] присвячені оперативному плануванню роботи станцій в умовах невизначеності та постійної мінливості, а також раціональній технології розподілу рухомого складу на залізничному полігоні. В цих роботах не було враховано технологію роботи вагонів приватних та іноземних. В дослідженнях [5-8] розглядаються інформаційні технології 3 організації управління вагонів операторських компаній, розробляється організаційнотехнологічна модель управління парком вантажних вагонів різних форм власності 3 урахуванням пріоритетного обслуговування вантажовідправників, вантажоодержувачів. Задача оптимального варіанта вибору кількості вагонів та їх форми власності за мінімальними значеннями сумарних експлуатаційних витрат вирішувалась в публікаціях [9, 10]. В [11] автори пропонують вагони операторських компаній відправляти за постійно визначеним маршрутом, що, на наш погляд, не $\epsilon$ раціонально в умовах недостачі транспортних ресурсів.

Визначення мети та задачі дослідження. При потенційній можливості зміни обсягів перевезень не обов'язково виконувати всі перевезення тільки за рахунок використання власних вагонів операторів. При плануванні слід враховувати ризик отримання витрат на утримання вагонів при непродуктивних простоях або несвоєчасній подачі вагонів під навантаження у зв'язку з їх недостачею. При цих умовах пропонується часткове використання вагонів інвентарного парку як резервного.

Основна частина дослідження. Питання ефективності використання рухомого складу виникає у разі простою вагонів, а також 3 вагонами, що належать іншим державам. Для ефективного управління доцільно розподілити вагони за формою власності, що дозволить виявити відхилення від виконання оперативного плану. Щоб стабілізувати ринок вантажних перевезень пропонується заміщення вагонів однієї форми власності на іншу. Для цього необхідне створення єдиної системи управління парком вантажних вагонів (ССУ ПВВ) [12]. Ця система повинна розглядатися в комплексі двох взаємозалежних елементів:

- взаємодія залізничної адміністрації та учасників Угоди про ССУ ПВВ;

- взаємодія залізничної адміністрації та операторських компаній.

Подібна схема ССУ ПВВ забезпечить:

a) підвищення ефективності керування перевізним процесом;

б) скорочення витрат власників рухомого складу на організацію бізнесу;

в) гарантоване забезпечення перевезення вантажів навантажувальними ресурсами залізничної адміністрації й інших власників;

г) скорочення часу проходження вагонів під вантажними операціями;

д) підвищення ефективності роботи рухомого складу внаслідок їм властивої універсальності;

е) зниження тарифного навантаження на користувачів послуг залізничного транспорту.

Об'єднання парків різних операторів дозволить розширити вантажну та клієнтську базу даних, що дає змогу проводити оптимізацію вагонопотоків, скорочувати витрати, удосконалити структуру парку рухомого складу, стабілізувати вагонообіг для досягнення зменшення пробігу, розподілу вагонопотоків на залізницях України. Доцільно заміняти їх вагонами іншої форми власності. Створення нового парку вагонів для взаємозаміни вагонів різних форм власності надає можливість заміни приватних вагонів на інвентарні та навпаки, у випадку нестачі того чи іншого рухомого складу - резервний парк вагонів. Згідно з цим, оптимізаційну модель розрахунку оперативного плану роботи залізничної станції можливо сформулювати так:

$$
\Delta R=\sum_{i=1}^{l} \sum_{p=1}^{k}\left(R_{i p}^{n \pi}-R_{i p}^{B u \kappa}\right) \rightarrow \min
$$

при цьому

$$
R_{i p}^{B u \kappa}=R_{i p}^{B \pi}+R_{i p}^{i H}+R_{i p}^{\text {y3 }} \text {. }
$$


Тоді

$$
\Delta R=\sum_{i=1}^{l} \sum_{p=1}^{k}\left(R_{i p}^{n \pi}-\left(R_{i p}^{B л}+R_{i p}^{i \mu}+R_{i p}^{y 3}\right)\right) \rightarrow \min
$$

при обмеженнях

$$
\left\{\begin{array}{l}
a^{1} \geq m_{n} \\
a^{2} \geq m_{n} \\
a^{3} \geq 1
\end{array}\right.
$$

де $\Delta R$ - параметр виконання плану;

$R_{i p}^{n л}$ - планована кількість поїздів, що перероблюються на станції (прибуття, відправлення, формування маршрутів);

$$
R_{i p}^{\text {вик }} \text { - реальне виконання поїзної роботи }
$$

станції;

$R_{i p}^{6 л}-$ кількість власних вагонів;

$R_{i p}^{i \mu}-$ кількість іноземних вагонів;

$R_{i p}^{y 3}-$ кількість вагонів, що належать Укрзалізниці;

$a^{1}$ - наявна кількість вагонів на станції та на підходах до неї для формування маршруту відправлення, ваг; $m_{n}-$ нормативна довжина маршруту на певному напрямку, ваг;

$a^{2}$ - наявна вивантажувальна спроможність підприємства, до якого призначено маршрут, ваг;

$a^{3}-$ кількість технічних станцій на шляху прямування маршруту.

Виходячи 3 цього, при відомих виробничо-технічних ресурсах і витратах на виконання робіт забезпечується максимальний ефект у досягненні поставленої мети (переробляти максимальну кількість вантажів, мінімізувати терміни доставки вантажів, забезпечувати максимальне збереження вантажів).

Висновок. Таким чином, оптимізаційна модель розрахунку оперативного плану вантажної роботи залізничної станції дасть можливість для збільшення обсягів перевезень, а також збільшення прибутку через зменшення обороту вагонів різних компаній-перевізників. Підвищення рівня ефективності використання та обороту вагонів за рахунок скорочення непродуктивних простоїв надасть додатковий ресурс для збільшення обсягів вантажоперевезень в Україні.

\section{Список використаних джерел}

1. Інструкція з оперативного планування поїзної і вантажної роботи на залізницях України [Текст]: № 969-ЦЗ, ЦД-0052: затв. наказом Укрзалізниці 15.12.04. - К.: Укрзалізниця, 2004.

2. Лаврухін, О.В. Формування оптимізаційної моделі розрахунку оперативного плану поїзної роботи залізничної станції [Текст] / О.В. Лаврухін, Ю.В. Доценко, П.В. Долгополов // Зб. наук. праць Укр. держ. акад. залізнич. трансп. - Харків: УкрДАЗТ, 2013. - Вип. 137. - С. 30-34.

3. Бутько, Т.В. Удосконалення технології організації перевезень в умовах невизначеності на основі раціонального використання засобів транспорту [Текст] / Т.В. Бутько, О.В. Лаврухін // Зб. наук. праць ДонІТЗ. - 2006. - Вип. 8. - С. 21-29.

4. Богомазова, Г.С. Проблема вибору раціонального варіанту організації вагонопотоків [Текст] / Г.С. Богомазова // Восточно-Европейский журнал передовых технологий. - 2011. - Вип. 1/3 (49). C. 33-35.

5. Данько, М.І. Удосконалення організаційно-технологічної моделі використання вантажних вагонів різної форми власності на залізницях України [Текст] / М.І. Данько, Д.В. Ломотько, В.В. Кулешов // Зб. наук. праць. - Харків: УкрДАЗТ, 2012. - Вип. 129. - С. 5-12. 
6. Кулешов, В.В. Удосконалення інформаційної технології роботи з вагонами різних форм власності з метою оптимізації пропускної спроможності залізничних транспортних систем [Текст] / В.В. Кулешов // Зб. наук. праць. - Харків: УкрДАЗТ, 2011. - Вип. 124. - С. 83-90.

7. Данько, М.I. Формування вимог до технології взаємодії залізничних адміністрацій i власників рухомого складу [Текст] / М.І. Данько, Д.В. Ломотько, В.М. Запара, В.В. Кулешов // Зб. наук. праць Укр. держ. акад. залізнич. трансп. - Харків: УкрДАЗТ, 2011. - Вип. 124 - С. 5-11.

8. Кулешов, В.В. Удосконалення технології перевезень парком вагонів операторських компаній на станціях вузла [Текст] / В.В. Кулешов, О.Ю. Толбатов, Т.Р. Чурилик // Зб. наук. праць Укр. держ. акад. залізнич. трансп. - Харків: УкрДАЗТ, 2013. - Вип. 135 - С. 107-11.

9. Лаврухин, А.В. Усовершенствование регулирования парка грузовых вагонов разных собственников [Текст] / А. В. Лаврухин, А. Е. Богомазова // Логистическое управление грузо- и вагонопотоками: Труды специалистов УкрГАЖТ. - Германия: Palmarium Academic Publishing, 2014. - C. 83-95.

10. Лаврухин, О.В. Наукові підходи до вдосконалення технології експлуатації вантажних вагонів всіх форм власності [Текст] / О.В. Лаврухин, Г.С. Бауліна, Г.С. Богомазова // Інформаційнокеруючі системи на залізничному транспоті. - Харків: УкрДУзТ. - С. 48-55.

11. Бутько, Т.В. Формалізація процесу управління парком вантажних вагонів операторських компаній [Текст] / Т.В. Бутько, О.Е. Шандер // Восточно-Европейский журнал передовых технологий. - 2014. - Вип. 2/3 (68) - С. 55-58.

12. Підвищення якості оперативного планування роботи вантажних вагонів всіх форм власності [Текст] / О.В. Лаврухин, Г.С. Богомазова // Людина, суспільство, комунікативні технології: матеріали III Міжнар. наук.-практ. конф. (Харків-Красний Лиман, 18-19 верес. 2015 р.) / УкрДУзТ Краснолиманська філія, Інст. філософії ім. Г. Сковороди НАН Укр., Краснолиман. Центр професійн. розвитку персоналу ДП «Донецька залізниця». - Харків, 2015. - С. 263.

Лаврухін Олександр Валерійович, д-р техн. наук, професор кафедри управління вантажною і комерційною роботою, Український державний університет залізничного транспорту. Тел.: (057)-730-10-85. E-mail: creattel@mail.ru.

Блиндюк Василь Степанович, д-р техн. наук, доцент, проректор з науково-педагогічної роботи, Український державний університет залізничного транспорту. Тел.: (057) 730-10-03.

Богомазова Ганна Євгенівна, асистент кафедри управління вантажною і комерційною роботою, Український державний університет залізничного транспорту. Тел.: (057)-730-10-85, 21-97. E-mail: anbogomazova@mail.ru. Киман Андрій Миколайович, аспірант кафедри управління вантажною і комерційною роботою, Український державний університет залізничного транспорту. Тел.: (057)-730-10-85.

Тофан Михайло Орестович, магістр групи 12-V-УППМ, Український державний університет залізничного транспорту. Tel.: (057) 730-10-85.

Розумович Роман Богданович, магістр групи МЗ-ОПУТ-Б-13, Український державний університет залізничного транспорту. Tel.: (057) 730-10-85.

Lavruhin Oleksandr Valeriovych d-r of techn. science, professor department of freight and commercial work Ukrainian State University of Railway Transport. Tel.: (057) 730-10-85. E-mail: : creattel@mail.ru.

Blindyuk Vasil Stepanovych, d-r of tech. science, associate professor, vice-rector for scientific and pedagogical work, Ukrainian State University of Railway Transport. Tel.: (057) 730-10-03.

Bogomazova Ganna Yevgenivna, assistant department of freight and commercial work Ukrainian State University of Railway Transport. Tel.: (057) 730-10-85, 21-97. E-mail: anbogomazova@mail.ru.

Kyman Andriy Mykolaiovych, graduate student department of freight and commercial work Ukrainian State University of Railway Transport. Tel.: (057) 730-10-85.

Tofan Mykhailo Orestovych master of a group 12-V-UPPM Ukrainian State University of Railway Transport. Tel.: (057) 730-10-85.

Rozumovych Roman Bogdanovych, master of a group MZ-OPUT-B-13 Ukrainian State University of Railway Transport. Tel.: (057) 730-10-85.

Стаття прийнята 04.09.15 p. 